\title{
Complement Receptor Type 2
}

National Cancer Institute

\section{Source}

National Cancer Institute. Complement Receptor Type 2. NCI Thesaurus. Code C104979.

Complement receptor type 2 (1033 aa, $\sim 113 \mathrm{kDa}$ ) is encoded by the human CR2 gene.

This protein plays a role in the activation of complement-mediated immunity. 